\title{
\begin{tabular}{l|l|l} 
Jurnal Eksplorasi Akuntansi & e-ISSN : 2656-3649 (Online) \\
Vol. 3, No 1, Februari 2021, Hal 32-49 & http://jea.ppj.unp.ac.id/index.php/jea
\end{tabular}
}

\section{Pengaruh Kualitas Sumber Daya Manusia, Pemanfaatan Teknologi Informasi Dan Komitmen Organisasi Terhadap Ketepatwaktuan Pelaporan Keuangan Pemerintah Nagari (Studi Empiris pada Pemerintah Nagari di Kabupaten Tanah Datar)}

\author{
Annisa Maharani ${ }^{1}$, Henri Agustin ${ }^{2}$ \\ 1,2 Jurusan Akuntansi Fakultas Ekonomi, Universitas Negeri Padang \\ *Korespondensi: thealova91@gmail.com
}

\begin{abstract}
This study aims to determine the effect of the quality of human resources, the use of information technology and organizational commitment to the timeliness of financial reporting by the village government (empirical study on Village Government of Tanah Datar Regency). This study uses subject data. The sampling technique used the total sampling method with a sample size of 75 villages. The data analysis used multiple linear regression analysis. The results showed that the quality of human resources and organizational commitment had a positive and significant effect on the timeliness of the Village government financial reporting. Information technology has no effect on the timeliness of the Village government financial reporting.
\end{abstract}

Keywords: Organizational commitment; quality of human resources; timeliness of village government financial reporting; utilization of information technology

How to cite

Maharani, Anisa \& Agustin, Henri. (2021). Pengaruh Kualitas Sumber Daya Manusia, Pemanfaatan Teknologi Informasi dan Komitmen Organisasi Terhadap Ketepatwaktuan Pelaporan Keuangan Pemerintah Nagari (Studi Empiris pada Pemerintah Nagari di Kabupaten Tanah Datar). Jurnal Eksplorasi Akuntansi, 3(1), 32-49.

\section{PENDAHULUAN}

Desa memiliki peran yang sangat penting dalam pelaksanaan tugas di bidang pelayanan publik. Dengan disahkan Undang-Undang Nomor 6 Tahun 2014 tentang desa beserta peraturan pelaksanaannya telah mengamanatkan pemerintah desa agar lebih mandiri dalam mengelola pemerintah dan sumber daya alam yang dimiliki termasuk dalam pengelolaan keuangan dan kekayaan milik desa. Pengelolaan keuangan desa menurut Peraturan Menteri Dalam Negeri Nomor 20 tahun 2018 merupakan keseluruhan kegiatan yang meliputi perencanaan, pelaksanaan, penatausahaan, pelaporan dan pertanggungjawaban keuangan desa. Laporan pertanggungjawaban disampaikan paling lambat 3 (tiga) bulan setelah akhir tahun anggaran berkenaan yang telah ditetapkan dengan Peraturan Desa.

Peraturan Pemerintah Nomor 71 tahun 2010 menjelaskan laporan keuangan merupakan laporan yang terstruktur mengenai posisi keuangan dan transaksi-transaksi yang dilakukan oleh suatu entitas pelaporan. Ketepatwaktuan laporan keuangan adalah tersedianya informasi bagi pembuat keputusan pada saat dibutuhkan sebelum kehilangan kekuatan dari 
informasi tersebut untuk mempengaruhi suatu keputusan. Ketepatwaktuan menunjukan rentang waktu antara penyajian informasi yang diinginkan dengan frekuensi informasi pelaporan. Apabila informasi tersebut tidak disampaikan dengan tepat waktu akan menyebabkan informasi tersebut kehilangan nilai dalam mempengaruhi kualitas keputusan (Yunina dan Wahyuni, 2016). Ketepatwaktuan merupakan karakteristik kualitatif yang penting dari akuntansi dan merupakan elemen yang mendasar dari relevansi informasi laporan keuangan (Clatworthy dan Peel, 2010).

Dalam konteks propinsi Sumatera Barat, ketepatwaktuan penyampaian laporan keuangan merupakan isu penting. Ada indikasi bahwa belum semua nagari mampu menyampaikan laporan keuangan nagari tepat waktu. Sebagai contoh, riset Agustin et.al (2017) di kabupaten Pasaman Barat menemukan bahwa nagari-nagari di kabupaten Pasaman Barat belum dapat mempertahankan konsistensi serta ketepatanwaktuan dalam menyampaikan laporan realisasi dan laporan pertanggung jawaban APBNagari setiap tahunnya kepada bupati.

Wardani dan Andriyani (2017) mengatakan bahwa ada tiga sumber yang mempengaruhi keandalan dan ketepatwaktuan yaitu: sumber daya manusia yang kompeten, dukungan sarana teknologi informasi yang memadai, dan komitmen organisasi yang baik. Hal pertama yang mempengaruhi adalah kualitas sumber daya Manusia (SDM). Dalam pengelolaan keuangan nagari yang baik, seorang wali nagari dan perangkat nagari yang terkait dengan sistem pelaporan keuangan harus memiliki sumber daya yang berkualitas. Sumber daya yang berkualitas tersebut harus didukung dengan latar belakang pendidikan, serta memiliki keterampilan, pengetahuan, dan kemampuan untuk melaksanakan suatu pekerjaan (Nurillah, 2014). Sumber daya yang berkualitas akan dapat menghemat waktu pembuatan laporan keuangan.

Menurut Jogiyanto (1995) informasi yang tepat waktu merupakan bagian dari nilai informasi (ketepatwaktuan) dapat dicapai dengan peran komponen teknologi. Informasi merupakan produk dari sistem teknologi informasi. Teknologi adalah jaringan komputer yang terdiri dari berbagai komponen pemrosesan informasi yang menggunakan berbagai jenis hardware, software, manajemen data, dan teknologi jaringan informasi. Komitmen organisasi sebagai suatu tindakan psikologis yang mempunyai karakteristik dengan meyakini dan menerima tujuan serta nilai yang dimiliki oleh organisasi, kesediaan untuk berusaha dengan sungguh-sungguh demi organisasi dan mempunyai keinginan yang kuat untuk tetap menjadi anggota organisasi. Pegawai yang memiliki komitmen organisasi akan bekerja dengan penuh dedikasi karena mereka telah menganggap bahwa pencapaian tujuan organisasi merupakan hal yang penting (Allen et al, 1993). Kepatuhan atas hukum dan peraturan akan terwujud apabila diikuti dengan oleh komitmen organisasi yang kuat (Ridha dan Basuki, 2012). Seorang staf pelaporan keuangan memiliki komitmen organisasi yang tinggi maka akan dapat meningkatkan timeliness pelaporan keuangan (Luthans, 2006).

Dari hasil pemaparan diatas beberapa peneliti terdahulu sudah meneliti adanya perbedaan pada penelitian sebelumnya yang menjadi research gap dari penelitian ini yaitu hasil penelitian Sembiring (2013) menunjukkan bahwa kualitas sumber daya manusia, pemanfaatan teknologi informasi, sistem pengendalian intern berpengaruh signifikan positif terhadap keandalan dan ketepatwaktuan pelaporan. Hasil penelitian Eristanti dkk (2019) menyatakan bahwa komitmen organisasi berpengaruh terhadap ketepatwaktuan pelaporan keuangan pemerintah. Berbeda dengan hasil penelitian Rosalind dan Kawedar (2011) yaitu kualitas sumber daya manusia tidak berpengaruh terhadap keandalan dan ketepatwaktuan laporan keuangan.

Berdasarkan latar belakang yang telah diuraikan diatas, dalam penyajian laporan keuangan harus disadari bahwa banyak pihak yang akan mengandalkan ketepatwaktuan dalam laporan keuangan tersebut. Salah satu tujuannya yaitu sebagai dasar dalam 
pengambilan keputusan. Oleh karena itu, informasi yang tersaji dalam laporan keuangan tersebut harus tepat waktu sehingga bermanfaat bagi para pemakai laporan keuangan. Berdasarkan fenomena tersebut maka peneliti tertarik untuk melakukan penelitian pada Nagari yang terdapat di Kabupaten Tanah Datar, maka peneliti mengambil judul "Pengaruh Kualitas Sumber Daya Manusia, Pemanfaatan Teknologi Informasi dan Komitmen Organisasi Terhadap Ketepatwaktuan Pelaporan Keuangan Pemerintah Nagari (Studi Empiris pada Pemerintah Nagari di Kabupaten Tanah Datar)".

\section{REVIUW LITERATUR DAN HIPOTESIS}

\section{Agency Theory}

Teori Utama yang mendasari penelitian ini adalah teori agency yang menjelaskan hubungan yang timbul karena adanya kontrak yang ditetapkan oleh rakyat (sebagai principal) yang menggunakan pemerintah (sebagai agent) untuk menyediakan jasa yang menjadi kepentingan rakyat (Jensen dan Meckling, 1976). Maka adanya tuntutan pertanggungjawaban kinerja keuangan oleh masyarakat yang mengharuskan pemerintah daerah untuk memberikan gambaran yang jelas tentang kinerjanya.

\section{Stewardship Theory}

Teori yang menggambarkan situasi dimana manajer tidaklah termotivasi oleh tujuan individu melainkan untuk kepentingan organisasi (Donaldson, 1991). Akuntansi sektor publik sejak awal perkembangannya telah dipersiapkan untuk memenuhi kebutuhan informasi yang menghubungkan antara stewards dan principals. Teori stewardship menjelaskan bahwa pemerintah sebagai suatu organisasi non profit yang bertujuan untuk mencapai good corporate governance.

\section{Teori Kepatuhan}

Teori kepatuhan sebelumnya telah diteliti pada ilmu sosial khususnya di bidang psikologis dan sosiologi yang lebih menekankan pada pentingnya proses sosialisasi dalam mempengaruhi perilaku kepatuhan seorang individu. Menurut Tyler dalam Septiani (2005), ada dua perspektif dasar dalam literatur sosiologi mengenai kepatuhan pada hukum, yaitu instrumental dan normatif. Perspektif instrumental mengasumsikan individu secara utuh didorong oleh kepentingan pribadi dan tanggapan terhadap perubahan-perubahan dalam insentif yang berhubungan dengan perilaku. Perspektif normatif berhubungan dengan apa yang di anggap seseorang sebagai moral dan berlawanan dengan kepentingan pribadi mereka.

\section{Ketepatwaktuan Pelaporan Keuangan}

Ketepatwaktuan adalah batasan penting pada publikasi laporan keuangan. Akumulasi, peringkasan, dan penyajian selanjutnya informasi akuntansi harus dilakukan secepat mungkin yang berguna untuk menjamin tersedia informasi ditangan pemakai atau pengguna. Ketepatwaktuan juga menunjukan rentang waktu antara penyajian informasi yang diinginkan dengan frekuensi pelaporan informasi. Apabila suatu informasi tidak disampaikan dengan tepat waktu maka akan menyebabkan kehilangan nilai informasi dalam mempengaruhi kualitas keputusan. Informasi tepat waktu akan mendukung manajer menghadapi ketidakpastian yang terjadi dalam lingkungan kerja mereka (Amey, Gordon dan Narayanan) dalam Respati (2001).

\section{Sumber Daya Manusia}

Menurut Widodo (2001) dalam Suwanda (2015), kualitas sumber daya manusia adalah kemampuan sumber daya manusia untuk melaksanakan tugas dan tanggung jawab yang diberikan kepadanya dengan bekal pendidikan, pelatihan dan pengalaman yang cukup 
memadai. Pegawai yang memiliki pemahaman yang rendah terhadap tugas dan fungsinya, serta adanya hambatan yang ditemukan dalam pengolahan data akan berdampak pada penyajian laporan keuangan.

\section{Pemanfaatan Teknologi Informasi}

Pemanfaatan Teknologi Informasi adalah tingkat integrasi teknologi informasi untuk melaksanakan tugas-tugas akuntansi (Zuliarti, 2012). Menurut Jogiyanto (1995) dalam Fadila (2013) informasi merupakan produk dari sistem teknologi informasi. Teknologi informasi berperan dalam menyediakan informasi yang bermanfaat bagi para pengambil keputusan yang ada di dalam organisasi termasuk dalam hal pelaporan sehingga mendukung proses pengambilan keputusan dengan lebih efektif.

\section{Komitmen Organisasi}

Komitmen organisasi merupakan keyakinan dan dukungan yang kuat terhadap nilai dan sasaran yang ingin dicapai organisasi (Mowday et al, 1979). Menurut Allen et al. (1993), Pegawai yang memiliki komitmen organisasi akan bekerja dengan penuh dedikasi karena mereka menganggap bahwa pencapaian tujuan organisasi merupakan hal yang penting. Pegawai yang memiliki komitmen organisasi yang tinggi memiliki pandangan yang positif dan melakukan yang terbaik untuk kepentingan organisasi, hal ini membuat seorang pegawai memiliki keinginan untuk memberikan tenaga dan tanggung jawab lebih demi keberhasilan organisasi.

\section{Pengembangan Hipotesis}

\section{Pengaruh Kualitas Sumber Daya Manusia Terhadap Ketepatwaktuan Pelaporan Keuangan Pemerintah Nagari}

Kualitas sumber daya manusia adalah kemampuan sumber daya manusia untuk melaksanakan tugas dan tanggungjawab yang diberikan kepadanya dengan bekal, pelatihan dan pengalaman yang cukup memadai. Pegawai yang memiliki pemahaman yang rendah terhadap tugas dan fungsinya, serta hambatan yang ditemukan dalam pegolahan data juga akan berdampak pada penyajian laporan keuangan. Sumber daya yang berkualitas juga dapat menghemat waktu pembuatan laporan keuangan, disebabkan karena sumber daya manusia tersebut telah mengetahui dan memahami apa yang akan dikerjakan dengan baik sehingga penyajian laporan keuangan bisa tepat waktu. Semakin cepat waktu penyajian laporan keuangan maka akan semakin baik untuk pengambilan keputusan (Mardiasmo, 2002). Maka hipotesis dalam penelitian ini adalah sebagai berikut:

$\mathbf{H}_{1}$ : Kualitas Sumber daya manusia berpengaruh positif terhadap ketepatwaktuan pelaporan keuangan pemerintah nagari.

\section{Pengaruh Pemanfaatan Teknologi Informasi Terhadap Ketepatwaktuan Pelaporan Keuangan Pemerintah Nagari}

Pemanfaatan teknologi informasi adalah manfaat yang diharapkan oleh pengguna teknologi informasi dalam melaksanakan tugasnya. Sistem akuntansi di pemerintah daerah maupun desa sudah pasti memiliki transaksi yang kompleks (Ariesta, 2013). Pemanfaatan teknologi informasi akan sangat membantu mempercepat proses pengolahan data transaksi dan penyajian laporan keuangan pemerintah sehingga laporan keuangan yang dihasilkan tidak kehilangan nilai informasi yaitu ketepatwaktuan. Oleh karena itu, pemanfaatan teknologi informasi akan membantu mempercepat proses pengelolaan data transaksi dan penyajian laporan keuangan, sehingga laporan keuangan tersebut tidak akan kehilangan nilai informasi yaitu ketepatwaktuan (Ariesta, 2013). Maka hipotesis dalam penelitian ini adalah sebagai berikut: 
$\mathbf{H}_{2}$ : Pemanfaatan teknologi informasi berpengaruh positif terhadap ketepatwaktuan pelaporan keuangan pemerintah nagari.

\section{Pengaruh Komitmen Organisasi Terhadap Ketepatwaktuan Pelaporan Keuangan Pemerintah Nagari}

Komitmen organisasi merupakan keyakinan dan dukungan yang kuat terhadap nilai dan sasaran yang ingin dicapai organisasi (Mowday et al, 1979). Menurut Allen et al. (1993), Pegawai yang memiliki komitmen organisasi akan bekerja dengan penuh dedikasi karena mereka menganggap bahwa pencapaian tujuan organisasi merupakan hal yang penting. Pegawai yang memiliki komitmen organisasi yang tinggi memiliki pandangan yang positif dan melakukan yang terbaik untuk kepentingan organisasi, hal ini membuat seorang pegawai memiliki keinginan untuk memberikan tenaga dan tanggung jawab lebih demi keberhasilan organisasi. Pada konteks pemerintahan, aparat yang memiliki komitmen organisasi yang tinggi, akan menggunakan informasi yang dimiliki untuk menyusun laporan keuangan menjadi relative lebih tepat. Dengan adanya komitmen organisasi yang tinggi maka akan dapat mempertahankan kepatuhan dalam penyajian laporan keuangan pemerintah yang reliable sesuai dengan SAP (Modo et al, 2016).Maka hipotesis dalam penelitian ini adalah sebagai berikut:

H3: Komitmen organisai berpengaruh positif terhadap ketepatwaktuan pelaporan keuangan pemerintah nagari.

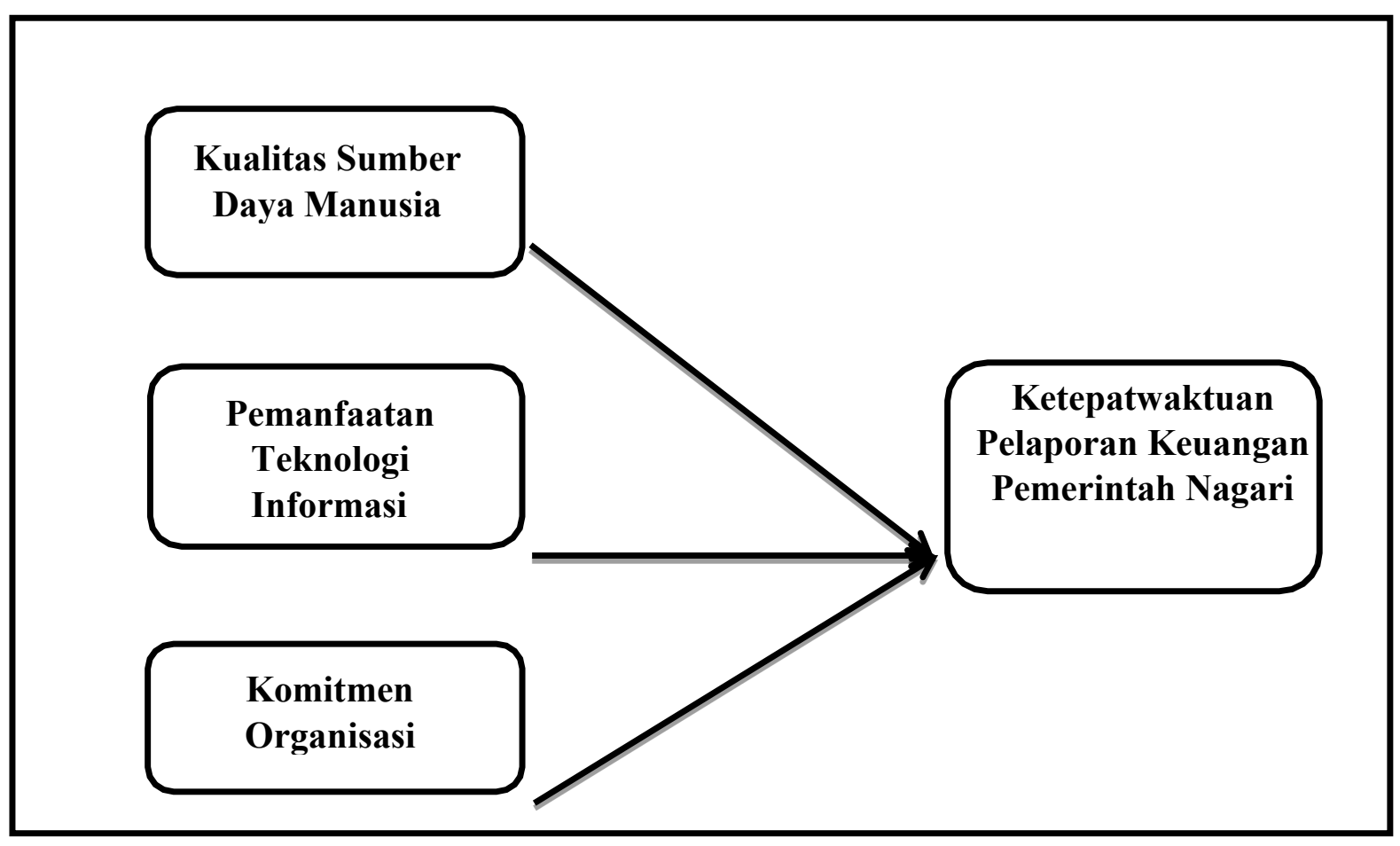

Gambar 1 Kerangka Konseptual

\section{METODE PENELITIAN}

\section{Desain Penelitian}

Jenis penelitian ini tergolong pada penelitian kausatif. Penelitian kausatif yaitu menganalisis pengaruh antara satu variabel dengan variabel lainnya (Sugiyono, 2008). 


\section{Populasi dan Sampel}

Populasi dalam penelitian ini yaitu pada pemerintah nagari di kabupaten Tanah Datar. Penelitian ini menggunakan teknik pengambilan sampel dilakukan secara Total Sampling. Sampel yang digunakan terdiri dari 75 nagari dengan jumlah responden 3 orang setiap nagari dan total responden dalam penelitian yaitu 225 responden.

\section{Jenis Data dan Sumber Data}

Jenis data pada penelitian ini adalah data subjek. Data berupa tanggapan tertulis atas pernyataan atau kuesioner dari subjek penelitian pada responden pemerintah nagari di Kabupaten Tanah datar. Sumber data penelitian ini adalah data primer.

\section{Teknik Pengumpulan Data}

Teknik pengumpulan data penelitian ini menggunakan kuesioner. Pemberian kuesioner dilakukan dengan cara memberikan pertanyaan atau pernyataan tertulis kepada responden untuk dijawab. Pernyataan dan pilihan jawaban disesuaikan dengan variabel-variabel yang akan diukur. Kuesioner diberikan kepada responden kemudian diambil kembali setelah diisi oleh responden dan paling lambat 1 minggu setelah penyerahan atau sesuai waktu yang telah disepakati dengan responden.

\section{Variabel Penelitian dan Pengukuran}

Variabel dependen dalam penelitian ini adalah ketepatwaktuan pelaporan keuangan Pemerintah Desa. Dalam penelitian ini yang menjadi variabel independen adalah kualitas sumber daya manusia, pemanfaatan teknologi informasi dan komitmen organisasi. Pengukuran variabel dalam penelitian ini menggunakan skala likert dengan empat alternatif jawaban dan masing-masing diberi skor 4-1 yaitu: Sangat Setuju (skor 4), Setuju (skor 3), Tidak Setuju (skor 2), Sangat Tidak Setuju (skor 1).

\section{Teknik Analisis Data \\ Verifikasi Data}

Verifikasi data merupakan pemeriksaan kembali kuesioner yang telah diisi oleh responden untuk memastikan agar semua pertanyaan sudah dijawab dengan lengkap oleh responden.

\section{Reliabilitas}

Ghozali (2006) menyatakan bahwa apabila jawaban seseorang dalam kuesioner konsisten atau stabil dari waktu ke waktu maka kuesioner tersebut dapat dikatakan reliabel. Untuk uji reliabilitas dilakukan pengujian croanbach alpha menurut Sekaran (2005).

\section{Uji Validitas}

Uji validitas berguna untuk mengukur sah atau tidak validnya suatu kuesioner. Apabila pernyataan pada kuesioner mampu mengungkapkan sesuatu yang telah diukur oleh kuesioner maka kuesioner tersebut dapat dikatakan valid. Teknik yang digunakan untuk uji validitas yaitu koefisien korelasi Pearson correlation.

\section{Uji Asumsi Klasik}

\section{Uji Normalitas}

Uji normalitas dapat dilakukan dengan metode kolmogorov smirnov, dengan melihat nilai signifikannya pada 0,05 . Jika nilai signifikan $<0,05$ maka dapat dikatakan data tidak berdistribusi normal, jika nilai signifikan $>0.05$ maka data tersebut berditribusi normal. 


\section{Uji Multikolinieritas}

Untuk menguji adanya multikolinieritas dapat dilihat melalui nilai variance inflantion faktor (VIF) dan toleransi. Jika nilai VIF $<10$ dan tolerance $>0,1$ maka tidak terjadi multikolinieritas tetapi jika nilai VIF $>10$ dan tolerance $>0,1$ maka terjadi multikolinieritas.

\section{Uji heteroskedastisitas}

Untuk menguji adanya heteroskedastisitas dapat menggunakan uji glejser. Dalam uji ini, apabila hasilnya nilai sig $>0,05$ maka tidak terdapat gejala heterokedastisitas, model yang baik yaitu tidak terjadi heterokedastisitas.

\section{Pengujian Hipotesis}

\section{Analisis Regresi Linier Berganda}

Analisis Regresi Linier berganda digunakan untuk meramalkan bagaimana keadaan (naik turunnya) variabel dependen, apabila dua variabel atau lebih variabel independen sebagai faktor predictor dimanipulasi (dinaikturunkan nilainya). Menurut Sugiono (2015) analisis ini dilakukan jika variabel independennya minimal dua yang dimasukkan dalam model regresi.

Persamaan regresi linier berganda

$$
\mathrm{Y}=\mathrm{a}+\mathrm{b}_{1} \mathrm{X}_{1}+\mathrm{b}_{2} \mathrm{X}_{2}+\mathrm{b}_{3} \mathrm{X}_{3}+\varepsilon
$$

Keterangan:

$\mathrm{Y} \quad=$ Ketepatwaktuan pelaporan keuangan pemerintah nagari

a $\quad=$ Konstanta

$\mathrm{b}_{1} \mathrm{~b}_{2} \mathrm{~b}_{3} \quad=$ Koefisien regresi model

$\mathrm{X}_{1} \quad=$ Kualitas sumber daya manusia

$\mathrm{X}_{2} \quad=$ Pemanfaatan teknologi informasi

$\mathrm{X}_{3} \quad=$ Komitmen organisasi

$\varepsilon \quad=$ error term model

\section{Uji F (F-test)}

Uji F bertujuan untuk menguji secara bersama-sama pengaruh variabel independen terhadap variabel dependen. Kriteria pengujiannya adalah jika $\mathrm{F}$ hitung $>\mathrm{F}$ tabel atau sign, 0,05 dan $\mathrm{F}$ hitung $<\mathrm{F}$ tabel atau sign 0,05 berarti model sign yang bisa digunakan untuk memprediksi pengaruh variabel independen secara bersama-sama terhadap variabel dependen. Dengan kepercayaan $(\alpha)$ untuk melihat pengujian hipotesis adalah $95 \%$ atau $(\alpha)=0,05$.

\section{Uji t (t-test)}

Uji statistik t digunakan untuk melihat seberapa jauh pengaruh satu variabel independen secara individual dalam menerangkan variabel-variabel dependen (Ghozali, 2011:64). Nilai signifikan kecil dari $0.05(\alpha=5 \%)$, maka variabel independen tersebut secara parsial berpengaruh signifikan terhadap variabel dependen, sehingga hipotesis diterima. Apabila nilai signifikan besar dari 0.05 maka variabel independen tersebut secara parsial tidak berpengaruh terhadap variabel dependen.

\section{Uji Koefisien Determinasi Adjusted R Square}

Uji Determinasi Adjusted $R$ Square digunakan apabila terdapat beberapa variabel independen dalam penelitian yang berguna untuk melihat seberapa jauh kemampuan model dalam menerangkan variansi variabel dependen. Nilai koefesien determinasi yaitunya antara nol dan 
satu, apabila nilai $\mathrm{R}^{2}$ mendekati 0 maka kemampuan variabel-variabel independen dalam menjelaskan variabel dependen terbatas. Nilai yang mendekati 1 berarti variabel-variabel independen memberikan semua informasi dalam memprediksi variasi variabel dependen (Ghozali, 2016).

\section{HASIL DAN PEMBAHASAN \\ Statistik Deskriptif}

Pendeskripsian terhadap variabel penelitian bertujuan agar dapat memberikan gambaran tentang masing-masing variabel yang akan diteliti.

Tabel 1 Descriptive Statistics

\begin{tabular}{|l|r|r|r|r|r|}
\hline \multicolumn{7}{|c|}{ Descriptive Statistics } \\
\hline & \multicolumn{1}{|c|}{ M } & \multicolumn{1}{|c|}{ Minimum } & Maximum & \multicolumn{1}{c|}{ Mean } & Std. Deviation \\
\hline Kualitas SDM & 169 & 15 & 40 & 32.83 & 4.013 \\
\hline Pemanfaatan TI & 169 & 7 & 24 & 21.59 & 2.624 \\
\hline Komitmen Organisasi & 169 & 19 & 28 & 23.95 & 2.626 \\
\hline Ketepatwaktuan PK & 169 & 8 & 12 & 10.72 & 1.258 \\
\hline Valid N (listwise) & 169 & & & & \\
\hline
\end{tabular}

Sumber: Data primer yang diolah, 2020

Dari Tabel diatas diketahui bahwa jumlah sampel yang digunakan dalam penelitian ini sebanyak 169 responden dari 75 nagari di kabupaten Tanah Datar. Untuk variabel kualitas sumber daya manusia tersebut diketahui memiliki nilai rata-rata sebesar 32,83 dengan standar deviasi 4,013 dengan nilai tertinggi 40,00 dan nilai terendah 15,00. Pemanfaatan teknologi informasi tersebut diketahui memiliki nilai rata-rata sebesar 21,59 dengan standar deviasi 2,624 dengan nilai tertinggi 24,00 dan nilai terendah 7,00. Untuk variabel komitmen organisasi memiliki nilai rata-rata sebesar 23,95 dengan standar deviasi 2,626 dengan nilai tertinggi 28,00 dan nilai terendah 19,00. Sedangkan untuk variabel ketepatwaktuan memiliki nilai rata-rata sebesar 10,72 dengan standar deviasi 1,258 dengan nilai tertinggi sebesar 12,00 dan nilai terendah 8,00 .

\section{Uji Validitas dan Realiabilitas Penelitian Uji Validitas}

Untuk melihat uji validitas dari masing-masing item kuesioner, digunakan Corrected Item-Total Colleration. Jika $r_{\text {hitung }}>r_{\text {tabel}}$, maka data dapat dikatakan valid, dimana $r_{\text {tabel }}$ untuk $\mathrm{N}=93$, adalah 0,206.

Tabel 2

Nilai Corrected Item-Total Correlation terkecil

\begin{tabular}{||l|c||}
\hline \multicolumn{1}{|c|}{ Nilai Corrected Item-Total Correlation terkecil } \\
\hline \multicolumn{1}{|c||}{ Instrumen Variabel } & $\begin{array}{c}\text { Nilai Corrected Item-Total } \\
\text { Correlation Terkecil }\end{array}$ \\
\hline $\begin{array}{l}\text { Ketepatwaktuan pelaporan keuangan pemerintah } \\
\text { Nagari }\end{array}$ & 0,523 \\
\hline Kualitas sumber daya manusia & 0,369 \\
\hline Pemanfaatan teknologi informasi & 0,660 \\
\hline Komitmen Organisasi & 0,380 \\
\hline
\end{tabular}

Sumber: Data primer yang diolah, 2020

\section{Uji Reliabilitas}

Untuk uji reliabilitas intrumen, semakin dekat koefisien keandalan dengan 1,0 maka akan semakin baik. Secara umum, keandalan yang kurang dari 0,60 dianggap buruk, keandalan yang dalam kisaran 0,70 bisa diterima, dan lebih dari 0,80 adalah baik (Sekaran, 2006). 
Tabel 3

Nilai Cronbach's Alpha

\begin{tabular}{||l|c||}
\hline \multicolumn{1}{|c|}{ Instrumen Variabel } & Nilai Cronbach's Alpha \\
\hline Ketepatwaktuan pelaporan keuangan daerah $(\mathrm{Y})$ & 0,769 \\
\hline Kualitas sumber daya manusia $\left(\mathrm{X}_{1}\right)$ & 0,878 \\
\hline Pemanfaatan teknologi informasi $\left(\mathrm{X}_{2}\right)$ & 0,897 \\
\hline Komitmen organisasi $\left(\mathrm{X}_{3}\right)$ & 0,798 \\
\hline
\end{tabular}

Sumber: Data primer yang diolah, 2020

\section{Uji Asumsi Klasik}

Uji Normalitas

Pengujian normalitas pada penelitian ini menggunakan One Sample KolmogorovSmirnov Test dengan taraf signifikan 0,05 atau 5\%. Jika nilai signifikan yang dihasilkan $>$ 0,05 maka distribusi data dikatakan normal. Sebaliknya jika nilai signifikan yang dihasilkan $<0,05$ maka data tidak terdistribusi secara normal.

Tabel 4

Uji Normalitas

\begin{tabular}{|l|l|r|}
\hline \multicolumn{2}{|c|}{ Uji Normalitas } \\
\hline \multicolumn{2}{|c|}{$\mathrm{N}$} & $\begin{array}{c}\text { Unstandardized } \\
\text { Residual }\end{array}$ \\
\hline Normal Parameters ${ }^{\mathrm{a}, \mathrm{b}}$ & Mean & .0000000 \\
\cline { 2 - 3 } & Std. Deviation & 1.13245494 \\
\hline Most Extreme Differences & Absolute & .105 \\
\cline { 2 - 3 } & Positive & .091 \\
\cline { 2 - 3 } & Negative & -.105 \\
\hline Test Statistic & .105 \\
\hline Asymp. Sig. (2-tailed) & $.000^{\mathrm{c}}$ \\
\hline a. Test distribution is Normal. \\
\hline
\end{tabular}

Sumber: Data primer yang diolah, 2020

Dari tabel di atas terlihat bahwa hasil uji normalitas menyatakan nilai test statistic sebesar 0,105 dengan signifikan 0,000. Berdasarkan hasil tersebut dinyatakan data yang digunakan dalam penelitian dinyatakan tidak berdistribusi normal.

\section{Uji Multikolinearitas}

Untuk menguji adanya multikolinearitas dapat dilihat melalui nilai variance inflantion factor (VIF) dan nilai tolerance value untuk masing-masing variabel independen. Jika nilai tolerance di atas 0,10 dan nilai VIF kurang dari 10 maka dikatakan tidak terdapat gejala multikolinearitas. 


\begin{tabular}{|c|c|c|c|}
\hline \multicolumn{4}{|c|}{ Tabel 5 Uji Multikolinearitas } \\
\hline \multirow{2}{*}{\multicolumn{2}{|c|}{ Model }} & \multicolumn{2}{|c|}{ Collinearity Statistics } \\
\hline & & Tolerance & VIF \\
\hline \multirow[t]{4}{*}{1} & (Constant) & & \\
\hline & Kualitas SDM & .810 & 1.234 \\
\hline & Pemanfaatan TI & .691 & 1.448 \\
\hline & Komitmen Organisasi & .633 & 1.579 \\
\hline
\end{tabular}

Sumber: Data primer yang diolah, 2020

Diperoleh nilai VIF untuk masing-masing variabel bebas kurang dari 10 dan nilai tolerance value berada diatas 0,10 . Hal ini menunjukkan tidak adanya korelasi antara sesama variabel bebas dalam model regresi dan dapat disimpulkan tidak terdapat masalah multikolinearitas diantara sesama variabel bebas dalam model regresi yang dibentuk.

\section{Uji Heterokedastisitas}

Untuk mendeteksi adanya heterokedastisitas dapat menggunakan uji Glejser. Dalam pengujian ini membandingkan signifikan dari uji ini apabila hasil nilai sig $>0,05$ atau $5 \%$. Jika signifikan di atas 5\% maka disimpulkan model regresi tidak mengandung adanya heterokedastisitas.

Tabel 6

Uji Heterokedastisitas

\begin{tabular}{|c|c|c|c|c|c|c|}
\hline \multicolumn{7}{|c|}{ Coefficients $^{a}$} \\
\hline & & \multicolumn{2}{|c|}{$\begin{array}{l}\text { Unstandardized } \\
\text { Coefficients }\end{array}$} & \multirow{2}{*}{$\begin{array}{c}\begin{array}{c}\text { Standardized } \\
\text { Coefficients }\end{array} \\
\text { Beta }\end{array}$} & \multirow[b]{2}{*}{$\mathrm{T}$} & \multirow[b]{2}{*}{ Sig. } \\
\hline \multicolumn{2}{|c|}{ Model } & $\mathrm{B}$ & Std. Error & & & \\
\hline \multirow[t]{4}{*}{1} & (Constant) & 4.804 & .958 & & 5.015 & .000 \\
\hline & Kualitas SDM & .056 & .024 & .179 & 2.305 & .022 \\
\hline & Pemanfaatan TI & .067 & .040 & .139 & 1.651 & .101 \\
\hline & $\begin{array}{l}\text { Komitmen } \\
\text { Organisasi }\end{array}$ & .110 & .042 & .229 & 2.603 & .010 \\
\hline
\end{tabular}

Sumber: Data primer yang diolah, 2020

Berdasarkan tabel di atas dapat dilihat tidak ada variabel yang signifikan dalam regresi dengan variabel ketepatwaktuan. Tingkat signifikan $>\alpha 0,05$, sehingga dapat disimpulkan bahwa model regresi yang digunakan dalam penelitian ini terbebas dari heteroskedastisitas. 


\section{Hasil Penelitian}

\section{Analisis Regresi Linear Berganda}

Tabel 7

Analisis Regresi Linear Berganda

\begin{tabular}{|c|c|c|c|c|}
\hline \multicolumn{5}{|c|}{ Coefficients $^{\mathrm{a}}$} \\
\hline \multirow{2}{*}{\multicolumn{2}{|c|}{ Model }} & \multicolumn{2}{|c|}{$\begin{array}{l}\text { Unstandardized } \\
\text { Coefficients }\end{array}$} & \multirow{2}{*}{$\begin{array}{c}\begin{array}{c}\text { Standardized } \\
\text { Coefficients }\end{array} \\
\text { Beta } \\
\end{array}$} \\
\hline & & $\mathrm{B}$ & Std. Error & \\
\hline \multirow[t]{4}{*}{1} & (Constant) & 4.804 & .958 & \\
\hline & Kualitas SDM & .056 & .024 & .179 \\
\hline & Pemanfaatan TI & .067 & .040 & .139 \\
\hline & Komitmen Organisasi & .110 & .042 & .229 \\
\hline
\end{tabular}

Sumber: Data primer yang diolah, 2020

Pada Tabel dapat dianalisis model estimasi sebagai berikut :

$$
\mathrm{Y}=4,804+0,056 \mathrm{X}_{1}+0,067 \mathrm{X}_{2}+0,110 \mathrm{X}_{3}+0.958
$$

Dari persamaan di atas dapat dilihat bahwa terdapat nilai konstanta sebesar 4,804 yang berarti bahwa adanya kualitas sumber daya manusia, pemanfaatan teknologi informasi dan komitmen organisasi pada pemerintah nagari di kabupaten Tanah Datar berada pada 4,804 satuan. Nilai koefisien dari variabel $X_{1}$ adalah sebesar 0,056 ini berarti bahwa dengan meningkatnya kualitas sumber daya manusia satu satuan, maka akan meningkatkan ketepatwaktuan pelaporan keuangan pemerintah nagari sebesar 0,056 satuan dengan bentuk pengaruh $\mathrm{X}_{1}$ terhadap $\mathrm{Y}$ yaitu berpengaruh positif. Nilai koefisien $\mathrm{X}_{2}$ adalah sebesar 0,067 ini berarti bahwa dengan meningkatnya pemanfaatan teknologi informasi satu satuan maka akan meningkatkan ketepatwaktuan pelaporan keuangan pemerintah nagari sebesar 0,067 satuan dan bentuk pengaruh $\mathrm{X}_{2}$ terhadap $\mathrm{Y}$ adalah positif. Nilai koefisian $\mathrm{X}_{3}$ adalah sebesar 0,110 ini berarti bahwa dengan meningkatnya komitmen organisasi satu satuan maka akan meningkatkan ketepatwaktuan pelaporan keuangan pemerintah nagari sebesar 0,110 satuan dan bentuk pengaruh $\mathrm{X}_{3}$ terhadap $\mathrm{Y}$ adalah positif.

\section{Uji F ( F Test $)$}

Nilai $F_{\text {tabel }}$ untuk $n=169$ pada $\alpha=0,05$ adalah 2,66. Nilai $F_{\text {hitung }}$ adalah 12,886 sedangkan nilai signifikansi adalah 0,000. Maka, $F_{\text {hitung }}>F_{\text {tabel }}$ dan nilai sig< $<0,05$. Berdasarkan hasil tersebut dapat diketahui bahwa model regresi yang digunakan merupakan model tetap.

\section{Tabel 8}

Uji F

\begin{tabular}{|c|c|c|c|c|c|c|}
\hline \multicolumn{7}{|c|}{ Uji F } \\
\hline \multicolumn{2}{|c|}{ Model } & Sum of Squares & Df & Mean Square & $\mathrm{F}$ & Sig. \\
\hline \multirow[t]{3}{*}{1} & Regression & 50.477 & 3 & 16.826 & 12.886 & $.000^{\mathrm{b}}$ \\
\hline & Residual & 215.452 & 165 & 1.306 & & \\
\hline & Total & 265.929 & 168 & & & \\
\hline \multicolumn{7}{|c|}{ a. Dependent Variable: Ketepatwaktuan PK } \\
\hline \multicolumn{7}{|c|}{ b. Predictors: (Constant), Komitmen Organisasi, Kualitas SDM, Pemanfaatan TI } \\
\hline
\end{tabular}

Sumber: Data primer yang diolah, 2020 


\section{Uji t (t-test)}

Uji $\mathrm{t}$ statistik ( $t$-test) bertujuan untuk mengetahui hubungan yang signifikan dari masing-masing variabel bebas terhadap variabel terikatnya. Pengujian hipotesis secara parsial dapat dilakukan dengan cara membandingkan nilai thitung dengan nilai $t_{\text {tabel. }}$. Nilai $t_{\text {tabel }}$ dengan $\alpha$ $=0,05$ dan derajat bebas $(\mathrm{db})=\mathrm{n}-\mathrm{k}-1=169-3-1=168$ adalah 1,654.

\section{Tabel 9}

Uji T

\begin{tabular}{|c|c|c|c|c|}
\hline \multicolumn{5}{|c|}{ Coefficients ${ }^{\mathrm{a}}$} \\
\hline \multirow{2}{*}{\multicolumn{2}{|c|}{ Model }} & \multirow[b]{2}{*}{$\mathrm{T}$} & \multirow[b]{2}{*}{ Sig. } & \multirow{2}{*}{$\begin{array}{c}\text { Hasil Hipotesis } \\
\text { Diterima/Tidak Diterima }\end{array}$} \\
\hline & & & & \\
\hline 1 & (Constant) & 5.015 & .000 & \\
\hline & Kualitas SDM & 2.305 & .022 & Diterima \\
\hline & Pemanfaatan TI & 1.651 & .101 & Tidak Diterima \\
\hline & Komitmen Organisasi & 2.603 & .010 & Diterima \\
\hline & ependent Variable: Ke & twaktua & & \\
\hline
\end{tabular}

Berdasarkan hasil olahan data statistik, maka dapat diketahui pengaruh antara variabel independen terhadap variabel dependen secara parsial sebagai berikut:

a) Hipotesis pertama dalam penelitian ini adalah kualitas sumber daya manusia berpengaruh positif terhadap ketepatwaktuan pelaporan keuangan pemerintah nagari. Berdasarkan tabel 1 diketahui $\mathrm{T}_{\text {hitung }}$ sebesar 2,305> $\mathrm{T}_{\text {tabel }}$ sebesar 1,654 dan nilai signifikan $0,022<0,05$ yang menunjukkan kualitas sumber daya manusia berpengaruh positif signifikan terhadap ketepatwaktuan pelaporan keuangan pemerintah nagari, sehingga dapat disimpulkan bahwa hipotesis 1 diterima.

b) Hipotesis kedua dalam penelitian ini adalah pemanfaatan teknologi informasi tidak berpengaruh terhadap ketepatwaktuan pelaporan keuangan pemerintah nagari. Berdasarkan tabel diketahui $\mathrm{T}_{\text {hitung }}$ sebesar 1,651 $<\mathrm{T}_{\text {tabel }}$ sebesar 1,654 dan nilai signifikan 0,101 >0,05 yang menunjukkan pemanfaatan teknologi informasi tidak berpengaruh terhadap ketepatwaktuan pelaporan keuangan pemerintah nagari, sehingga dapat disimpulkan bahwa hipotesis 2 tidak diterima.

c) Hipotesis ketiga dalam penelitian ini adalah komitmen organisasi berpengaruh positif terhadap Ketepatwaktuan pelaporan keuangan pemerintah nagari. Berdasarkan tabel

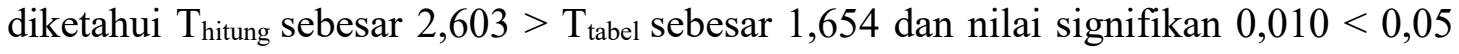
yang menunjukkan komitmen organisasi berpengaruh positif signifikan terhadap ketepatwaktuan pelaporan keuangan pemerintah nagari, sehingga dapat disimpulkan bahwa hipotesis 3 diterima.

\section{Uji Koefisien Determinasi Adjusted $R$ Square}

Uji Determinasi Adjusted $R$ Square digunakan apabila terdapat beberapa variabel independen dalam penelitian yang berguna untuk melihat seberapa jauh kemampuan model dalam menerangkan variansi variabel dependen. 
Tabel 10

Hasil Uji Determinasi Adjusted R Square

\begin{tabular}{|c|c|c|c|c|c|}
\hline \multicolumn{6}{|c|}{ Model Summary } \\
\hline Model & $\mathrm{R}$ & R Square & $\begin{array}{l}\text { Adjusted R } \\
\text { Square }\end{array}$ & $\begin{array}{l}\text { Std. Error of } \\
\text { the Estimate }\end{array}$ & Durbin-Watson \\
\hline 1 & $.436^{\mathrm{a}}$ & .190 & .175 & 1.143 & 1.591 \\
\hline
\end{tabular}

Sumber: Data Primer yang diolah, 2020

Dari hasil output diatas menunjukkan besarnya nilai Adjusted $\mathrm{R}^{2}$ adalah 0,175 atau 17,5\%. Hal ini berarti bahwa besar pengaruh dapat dijelaskan oleh variasi dari variabel independen (kualitas sumber daya manusia, pemanfaatan teknologi informasi dan komitmen organisasi) terhadap variabel dependen (Ketepatwaktuan Pelaporan Keuangan Nagari) adalah $17,5 \%$.

\section{PEMBAHASAN}

\section{Pengaruh Kualitas Sumber Daya Manusia Terhadap Ketepatwaktuan Pelaporan Keuangan Pemerintah Nagari.}

Hasil penelitian ini menunjukkan bahwa kualitas sumber daya manusia berpengaruh positif signifikan terhadap ketepatwaktuan pelaporan keuangan pemerintah nagari. Artinya, semakin baik kualitas sumber daya manusia, maka akan semakin baik juga ketepatwaktuan pelaporan keuangan nagari. Hal ini sejalan dengan penelitian Indriasari (2008) menunjukkan bahwa kualitas sumber daya manusia berpengaruh positif signifikan terhadap ketepatwaktuan pelaporan keuangan pemerintah daerah. Ketika seseorang memiliki kualitas yang dibutuhkan untuk melaksanakan suatu pekerjaan atau tugas yang menjadi tanggung jawabnya maka ia akan menyelesaikan pekerjaan/tugasnya dengan baik dan lebih cepat. Hasil penelitian ini sejalan dengan penelitian Winidyaningrum dan Rahmawati (2010) yang menunjukkan bahwa sumber daya manusia akan sangat membantu mempercepat penyajian laporan keuangan pemerintah sehingga laporan keuangan tersebut menjadi tepat waktu.

Penelitian Lismawati (2011) menemukan kemampuan sumber daya manusia berpengaruh positif terhadap ketepatwaktuan pelaporan keuangan pemerintah daerah. Hal ini menunjukan bahwa kemampuan sumber daya manusia atau pegawai dapat mempengaruhi ketepatwaktuan dari pelaporan keuangan pemerintah daerah. Dapat disimpulkan bahwa hasil penelitian ini mendukung Stewardship Theory yang menyatakan bahwa para eksekutif cenderung akan termotivasi untuk bertindak dalam kepentingan korporasi dibandingkan dengan kepentingan mereka sendiri. Dengan demikian peran kualitas sumber daya manusia sangat diperlukan dalam pembuatan laporan keuangan desa (Atikah, 2019). Hasil penelitian ini menyimpulkan bahwa semakin baik kualitas sumber daya manusia dalam pemerintah nagari akan meningkatkan ketepatwaktuan pelaporan keuangan pemerintah nagari menjadi baik. Hasil penelitian menunjukkan bahwa kualitas sumber daya manusia berpengaruh positif dan siginfikan terhadap ketepatwaktuan pelaporan keuangan pemerintah nagari.

\section{Pengaruh Pemanfaatan Teknologi Informasi Terhadap Ketepatwaktuan Pelaporan Keuangan Pemerintah Nagari}

Hasil penelitian ini menunjukkan bahwa pemanfaatan teknologi informasi tidak berpengaruh terhadap ketepatwaktuan pelaporan keuangan pemerintah nagari. Hal ini sejalan dengan penelitian hasil penelitian Prapto (2010) menemukan bahwa pemanfaatan teknologi tidak berpengaruh signifikan terhadap ketepatwaktuan pelaporan keuangan pemerintah daerah. Penelitian ini menjelaskan bahwa pemanfaatan teknologi informasi yang masih mengalami kendala karena peralatan dan software pendukung yang masih sering mengalami 
kendala sehingga membutuhkan waktu perbaikan yang cukup lama yang berdampak pada jadwal waktu pelaporan yang mengalami penyesuaian atau mengalami kemunduran dan ini berimplikasi pada ketidaktepatan pelaporan keuangan pemerintah daerah.

Perkembangan berbagai macam teknologi informasi terutama komputer dan internet membuat pergeseran tata cara pelayanan publik menjadi sistem online yang terkomputerisasi. Dalam hal penyusunan pelaporan keuangan nagari telah memanfaatkan berbagai software yang dapat digunakan untuk menyusun laporan keuangan. Penggunaan software akuntansi tersebut dapat berdampak pada peningkatan kualitas terutama berkaitan dengan akurasi dan kecepatan. Peneliti berpendapat bahwa untuk saat ini masih terdapat kendala jaringan internet pada suatu nagari, di samping itu sumber daya manusia yang masih perlu dilakukan pelatihan untuk meningkatkan keahlian dan profesionalitas dalam menyusun laporan keuangan agar semua nagari melaporkan laporan keuangan dengan tepat waktu. Keterbatasan kemampuan sumber daya manusia juga merupakan salah satu faktor penentu ketepatwaktuan pelaporan keuangan. Teknologi informasi yang canggih tidak akan menghasilkan pelaporan keuangan yang akurat dan cepat apabila sumber daya manusia yang ada tidak dapat mengoptimalkan kemampuan teknologi tersebut (Prapto, 2010).

Hasil penelitian ini menyimpulkan bahwa semakin baik pemanfaatan teknologi informasi dalam pemerintah nagari tidak berpengaruh terhadap ketepatwaktuan pelaporan keuangan pemerintah nagari. Hasil penelitian menunjukkan bahwa pemanfaatan teknologi informasi tidak berpengaruh terhadap ketepatwaktuan pelaporan keuangan pemerintah nagari.

\section{Pengaruh Komitmen Organisasi Terhadap Ketepatwaktuan Pelaporan Keuangan Pemerintah Nagari.}

Hasil penelitian ini menunjukkan bahwa komitmen organisasi berpengaruh positif signifikan terhadap ketepatwaktuan pelaporan keuangan pemerintah nagari. Artinya, semakin baik komitmen organisasi maka dapat meningkatkan ketepatwaktuan pelaporan keuagan pemerintah nagari. Hal ini sejalan dengan penelitian studi Luthans (2006) menyatakan bahwa semakin seorang staf pelaporan keuangan memiliki komitmen organisasi yang tinggi maka dapat meningkatkan timeliness pelaporan keuangan. Sejalan dengan hasil penelitian Rosalind dan Kawedar (2011) dan Rahcmawati (2014) menghasilkan komitmen organisasi berpengaruh signifikan terhadap ketepatan waktu. Hasil penelitian Eristansi dkk (2019) menyatakan bahwa komitmen organisasi berpengaruh terhadap ketepatan waktu pelaporan keuangan pemerintah kabupaten Lombok Barat. Dapat disimpulkan bahwa penelitian ini mendukung stewardship theory mengargumentasikan bahwa untuk kepentingan organisasi manajemen termotivasi untuk lebih fokus pada sasaran utama dari pada tujuan-tujuan individu. Luthans (2006) menyatakan bahwa keinginan kuat untuk tetap menjadi sebagai anggota organisasi tertentu, keinginan untuk berusaha keras sesuai dengan keinginan organisasi, keyakinan tertentu, dan penerimaan nilai dan tujuan organisasi merupakan komitmen organisasi.

Hasil penelitian ini menyimpulkan bahwa semakin baik komitmen organisasi dalam pemerintah nagari di kabupaten Tanah Datar akan meningkatkan ketepatwaktuan pelaporan keuangan pemerintah nagari menjadi baik. Hasil penelitian menunjukkan bahwa komitmen organisasi berpengaruh positif dan siginfikan terhadap ketepatwaktuan pelaporan keuangan pemerintah nagari.

\section{SIMPULAN, KETERBATASAN, SARAN Simpulan}

Dari hasil pengolahan data dan pembahasan terhadap hasil penelitian pengaruh kualitas sumber daya manusia, pemanfaatan teknologi informasi dan komitmen organisasi 
terhadap ketepatwaktuan pelaporan keuangan pemerintah nagari maka dapat diambil kesimpulan sebagai berikut :

1. Kualitas sumber daya manusia positif signifikan terhadap ketepatwaktuan pelaporan keuangan pemerintah nagari di kabupaten Tanah Datar. Dimana semakin baik kualitas sumber daya manusia maka semakin baik pula ketepatwaktuan pelaporan keuangan pemerintah nagari.

2. Pemanfaatan teknologi informasi tidak berpengaruh terhadap ketepatwaktuan pelaporan keuangan pemerintah nagari di kabupaten Tanah Datar.

3. Komitmen organisasi positif signifkan terhadap ketepatwaktuan pelaporan keuangan pemerintah nagari di kabupaten Tanah Datar. Dimana semakin baik komitmen organisasi maka semakin baik pula ketepatwaktuan pelaporan keuangan pemerintah nagari.

\section{Keterbatasan}

Pada penelitian ini ada beberapa keterbatasan antara lain sebagai berikut:

1. Peneliti menggunakan kuesioner dalam pengumpulan data. Penggunaan kuesioner tersebut dapat mengakibatkan respon yang bias dari responden akibat ketidakseriusan dan ketidakjujuran responden terhadap apa yang dirasakan dalam menjawab pertanyaan kuesioner. Sedikitnya jumlah responden yang diperoleh mengurangi derajat keterwakilan pegawai pemerintah nagari.

2. Pada penelitian ini menunjukkan bahwa uji Adjusted $\mathrm{R}^{2}$ adalah sebesar $0,175 \%$ atau sebesar 17,5\% variabel ketepatwaktuan pelaporan keuangan nagari dapat dijelaskan oleh variabel independen. Sedangkan sisanya $(100 \%-17,5 \%) \quad 82,5 \%$ dijelakan oleh variabel lain yang tidak diteliti pada penelitian ini.

\section{Saran}

1. Bagi instansi pemerintah diharapkan agar dapat lebih meningkatkan kinerjanya dalam pengelolaan keuangan nagari dengan memperhatikan dan meningkatkan kualitas sumber daya manusia, pemanfaatan teknologi informasi, dan adanya komitmen organisasi yang memadai, sehingga diharapkan pihak pengelola keuangan nagari khususnya bagian akuntansi mampu melaksanakan tugas dan fungsi akuntansi dengan baik agar pelaporan keuangan pemerintah nagari yang tepat waktu sehingga dapat digunakan dalam pengambilan keputusan.

2. Bagi peneliti selanjutnya sebaiknya pengamatan dilakukan langsung pada objek penelitian untuk menghindari terjadinya respon bias akibat dari penggunaan kuesioner. Sebaiknya dilengkapi dengan wawancara agar partisipasi responden lebih tinggi dan mendapatkan informasi yang lebih akurat serta dipercayai kebenarannya. Melakukan penambahan sampel penelitian agar dapat memaksimalkan keterwakilan dari pegawai pemerintah nagari secara menyeluruh.

3. Bagi peneliti selanjutnya diharapkan menambahkan variabel lain yang mampu mengukur faktor-faktor yang mempengaruhi ketepatwaktuan pelaporan keuangan pemerintah nagari seperti : gaya kepemimpinan wali nagari, tingkat pendidikan, integritas, objektivitas, dan tingkat profitabilitas. 


\section{DAFTAR PUSTAKA}

Alimbudiono, S, R., \& Arastyo A, F. (2004). Kesiapan Sumber Daya Manusia Sub Bagian Akuntansi Pemerintah daerah "XYZ" dan Kaitannya dengan Pertanggungjawaban Keuangan Daerah Kepada Masyarakat . Jurnal Akuntansi dan Keuangan Sektor Publik.

Agustin, H., Arza, F. I., Mulyani, E., \& Fitra, H. (2017). Potret Pertanggung Jawaban dan Pelaporan dan Keuangan Nagari di Kabupaten Pasaman Barat. Wahana Riset Akuntansi. 5(2).1019-1028.

Arista, F. (2013). Pengaruh Kualitas Sumber Daya Manusia, Pemanfaatan Teknologi Informasi dan Sistem Pengendalian Intern Terhadap Keandalan dan Ketepatwaktuan Pelaporan Keuangan Pemerintah (Studi Empiris Pada Pemerintah Kota Padang). Jurnal Akuntansi Universitas Negeri Padang.

Aritonang, \& F.S. (2009). Faktor-Faktor Pendukung Keberhasilan Penerapan Peraturan Pemerintah No.24 Tahun 2005 Pada Pemerintahan Kabupaten Labuhan Batu. Jurnal Akuntansi.

Astrawan, K. P., Wahyuni, M. A., \& Herawati, N. T. (2016). Pengaruh Sistem Informasi Akuntansi, Kapasitas Sumber Daya Manusia, Pengendalian Intern, dan Pengawasan Keuangan Pemerintah Daerah Terhadap Ketepatwaktuan Pelaporan Keuangan Pemerintah Daerah Pada SKPD Kabupaten Buleleng. E-Jurnal S1 Ak Universitas Pendidikan Ganesha.

Atikah, A. 2019. Pengaruh Sistem Keuangan Desa,Kompetensi SDM,dan Sistem Pengendalian Internal Terhadap Kualitas laporan Keuangan Desa. Skripsi Universitas jember.

Bastian, I. (2007). Sistem Akuntansi Sektor Publik. Jakarta: Salemba Empat.

Cohen, S. (2007). Assessing It As A Key Success Factor For Accrual Accounting Implementation In Greek Municipalities. Journal of Financial Accountability \& Management.

Daniri, M. (2005). Good Corporate Governance: Konsep dan Penerapannya dalam Konteks Indonesia. Jakarta: Ray Indonesia.

Darmini, A. A., \& Putra, I. N. (2006). Pemanfaatan Teknologi Informasi dan Pengaruhnya Pada Kinerja Individual Pada Bank Perkreditan Rakyat di Kabupaten Tabanan. EJurnal Akuntansi Universitas Udayana.

Eristanti, B. D., \& Putra, I. N. (2018). Faktor-Faktor Yang Mempengaruhi Ketepatan Waktu Pelaporan Keuangan Pemerintah Daerah. Jurnal Studi Akuntansi dan Keuangan.

Eristanti, B., \& Ardana, I. N. (2019). Faktor-Faktor Yang Mempengaruhi Ketepatan Waktu Pelaporan Keuangan Pemerintah Daerah. Jurnal Studi Akuntansi dan Keuangan.

Fadila, A. (2013). Pengaruh Kualitas Sumber Daya Manusia, Pemenfaatan Teknologi Informasi, dan Pengendalian Intern Terhadap Nilai Informasi Laporan Keuangan Pemerintah Daerah. Jurnal Akuntansi.

Ghozali, I. (2016). Aplikasi Analisis Multivariante Dengan Program SPSS. Semarang: Badan Penerbit UNDIP.

Harifan, H. (2009). Pengaruh Kapasitas Sumber Daya Manusia, Pemanfaatan Teknologi Informasi dan Pengendalian Intern Akuntansi Terhadap Nilai Informasi Laporan Keuangan Pemerintah Daerah pada SKPD Pemerintah Kota Padang. Skripsi: Fakultas Ekonomi Universitas Negeri Padang.

Havesi, G. A. (2005). Standards For Internal Control In New York State Government. www.osc.state.ny.us.

Indriasari, D., \& Nahartyo, E. (2008). Pengaruh Kapasitas SDM, Pemanfaatan Teknologi Informasi dan Pengendalian Intern Akuntansi Terhadap Keterandalan dan Ketepatwktuan pelaporan keuangan Pemerintah daerah (Studi Pada Pemerintah Kota 
Palembang dan Kabupaten Ogan Ilir). Simposium Nasional Akuntansi XI. Pontianak. Jasen, M., \& W, M. (1976). Theory of the Firm: Manegerial Behavior, Agency and Ownership Structure. Journal of Financial Economic.

Jogiyanto. (2008). Metodologi Penelitian Sistem Informasi. CV Andi Offset: Yogyakarta.

Kartika, \& Safitri, H. (2017). Pengaruh Kualitas Sumber Daya Manusia dan Pemanfaatan Teknologi Informasi Terhadap Keandalan dan Ketepatwaktuan Pelaporan Keuangan Pemerintah Daerah. Jurnal Akuntansi Universitas Jember, 15(2).

Larasati, P. 2017. Pengaruh Pemanfaatan Teknologi Informasi, Pengawasan Keuangan Daerah, Sumber Daya Manusia dan Pengendalian Intern Akuntansi Terhadap Keterandalan Pelaporan Keuangan Pemerintah Daerah.

Lismawati. (2011). Pengaruh Kemampuan Sumber Daya Manusia Terhadap Keterandalan dan Ketepatwaktuan Pelaporan Keuangan pemerintah Daerah. Jurnal Universitas Sultan Agung Tirtayasa Serang Banten.

Lubis, A. I. (2010). Akuntansi Keperilakuan. Edisi Ke Dua. Jakarta: Salemba Empat.

M.Dawan, R. (2010). Intelektual, intelegasi, dan Perilaku Politik dan Bangsa. Bandung: Mizan.

Mahmudi. (1997). Akuntansi Manajemen: Konsep, Manfaat dan Terakayasa. Yogyakarta: STIE YKPN.

Mardiasmo. (2002). Akuntansi Sektor Publik. Edisi Pertama. Yogyakarta: Penerbit Andi.

Momuat, C. P. (2016). Pengaruh Pemanfaatan Teknologi Informasi terhadap ketepatan Waktu pelaporan Keuangan Dalam Rangka Mewujudkan Transparansi dan Akuntabilitas (Studi Pada Kabupaten Minahasa Tenggara). Jurnal EMBA.

Mutiana, Liza, Diantimala, Y., \& Z. (2017). Pengaruh Sistem Pengendalian Intern, Teknologi Informasi, Kualitas Sumber Daya Manusia dan Komitmen Organisasi Terhadap Kualitas Laporan Keuangan . Jurnal Perspektif Ekonomi Darussalam.

N.J, A., \& Meyer, J. (1990). The Measurement and Antecedents of Affective, Continuance, and Normative Commitment to the Organization. Journal of Occupational Psychology.

Nihayah, A. (2015). Pengaruh Sumber Daya Manusia, Pemanfaatan Teknologi Informasi, Pengendalian Internal Terhadap Ketepatwaktuan dan Keterandalan Pelaporan Keuangan Pemerintah Daerah (Studi Empiris pada DPPKAD Eks Keresidenan Pati). Jurnal, Universitas Muhammadiyah Surakarta.

Nurillah, A. S. (2014). Pengaruh Kompetensi Sumber Daya Manusia, Penerapan Sistem Akuntansi Keuangan Daerah (SAKD), Pemanfaatan Teknologi Informasi dan Sistem Pengendalian Intern Terhadap Kualitas Laporan Keuangan Pemerintah Daerah (Studi Empiris Pada SKPD Kota Depok). Skripsi, Fakultas Ekonomika dan Bisnis Universitas Diponegoro.

Peraturan Pemerintah Nomor 71 tahun 2010 Tentang Standar Akuntansi Pemerintahan.

Peraturan Pemerintah Nomor 71 tahun 2010 Tentang Standar Akuntansi Pemerintahan.

Peraturan Pemerintah Nomor 71 Tahun 2010 Tentang Standar Akuntansi Pemerintahan.

Peraturan Pemerintah Nomor 71 Tahun 2010 Tentang Standar Akuntansi Pemerintahan.

Permendagri Nomor 113 Tahun 2014 Tentang Pengelolaan Keuangan Desa.

Prapto, S. (2010). Pengaruh Pemanfaatan Teknologi Informasi, dan Pengendalian Intern Akuntansi Terhadap Keterandalan dan Ketepatwaktuan Pelaporan Keuangan Pemerintah Daerah. Jurnal Akuntansi Universitas Sebelas Maret.

Primayana, Atmadja, \& Darmawan. (2014). Pengaruh Kapasitas Sumber Daya Manusia, Pengendalian Intern Akuntansi, Pemanfaatan Teknologi Informasi dan Pengawasan Keuangan Daerah Terhadap Keterandalan Pelaporan Keuangan Pemerintah Daerah (Studi Empiris Pada Pemerintah Daerah Kabupaten Sukoharjo). Jurnal Akuntansi Program S1. 
Respati, N. W. 2001. Faktor-Faktor Yang Berpengaruh Terhadap Ketepatan Waktu Pelaporan Keuangan. Skripsi. Fakultas Ekonomi Universitas Diponegoro, Semarang.

Robbins, P., Stephen, \& A.Judge, T. (2008). Perilaku Organisasi Edisi Ke-12. Jakarta: Salemba Empat.

Rosalin, F. (2011). Faktor-Faktor yang Mempengaruhi Keandalan dan Timeliness Pelaporan Keuangan Badan Layanan Umum (Studi Pada BLU di Kota Semarang). Skripsi Universitas Diponegoro: Semarang.

Rosalin, Faristina, \& Kawedar, W. (2011). Faktor-Faktor Yang Mempengaruhi Keandalan dan Timeliness Pelaporan Keuangan Badan Layanan Umum (Studi Pada BLU di Kota Semarang). Retrieved from http://eprints.undip.ac.id/29439/1/jurnal.pdf.

Sembiring, F. L. (2013). Pengaruh Kualitas Sumber Daya Manusia, Pemanfaatan Teknologi Informasi dan Pengendalian Intern Akuntansi Terhadap Nilai Informasi Pelaporan Keuangan Pemerintah Daerah (Studi Pada Satuan Kerja Perangkat Daerah di Kabupaten Pasaman Barat). Jurnal, Universitas Negeri Padang .

Soekidjan. (2009). Manajemen Sumber Daya. Jakarta: Bumi Agsara.

SP, R., \& Judge. (2008). Perilaku Organisasi. Buku 2. Jakarta: Salemba Empat.

Sukirman, Sularso, \& Nugraheni. (2012). Faktor-Faktor Yang Mempengaruhi Keterandalan dan Ketepatwaktuan Pelaporan Keuangan dengan Pengendalian Intern Akuntansi Sebagai Variabel Pemoderasi. Jurnal, Universitas Jenderal Soedirman.

Sulina, I. G., Wahyuni, M. A., \& Kurniawan, P. S. (2017). Peranan Sistem Keuangan Desa (SISKEUDES) Terhadap Kinerja Pemerintah Desa. E-Jurnal Akuntansi Universitas Pendidikan Ganesha.

Suwardjono. (2005). Teori Akuntansi: Perekayasaan Pelaporan Keuangan. Edisi Ketiga. Yogyakarta. BPFE.

Wahyono, T. (2004). Sistem Informasi Akuntansi: Analisa, Desain dan Pemograman Komputer. Yogyakarta: Penerbit Andi.

Widjajanto, N. (2001). Sistem Informasi Akuntansi. Jakarta: Erlangga.

Winidyaningrum, C., \& Rahmawati. (2010). Pengaruh Sumber Daya Manusia dan Pemanfaatan Teknologi Informasi Terhadap Keterandalan dan ketepatwaktuan Pelaporan Keuangan Pemerintah Daerah Dengan Variabel Intervening Pengendalian Intern Akuntansi. Simposium Nasional Akuntansi XIII. Purwokerto.

Yosefrinaldi. 2013. Pengaruh Kapasitas Sumber Daya Manusia dan Pemanfaatan Teknologi Informasi Terhadap Kualitas Laporan Keuangan Pemerintah Daerah dengan Variabel Intervening Pengendalian Intern Pemerintah (Studi Empiris pada Dinas Pengelolaan Keuangan dan Aset Daerah) . Skripsi. Universitas Negeri Padang.

Zetra. (2009). Pengaruh Sumber Daya Manusia dan Pemanfaatan Teknologi Terhadap Nilai Informasi Pelaporan Keuangan Pemerintah. Jurnal, Universitas Gadjah Mada. Yogyakarta.

Zuliarti. (2012). Pengaruh Kapasitas Sumber Daya Manusia, Pemanfaatan Teknologi Informasi dan Pengendalian Intern Akuntansi Terhadap Nilai Informasi Pelaporan Keuangan Pemerintah Daerah. Skripsi, Universitas Muria Kudus. 